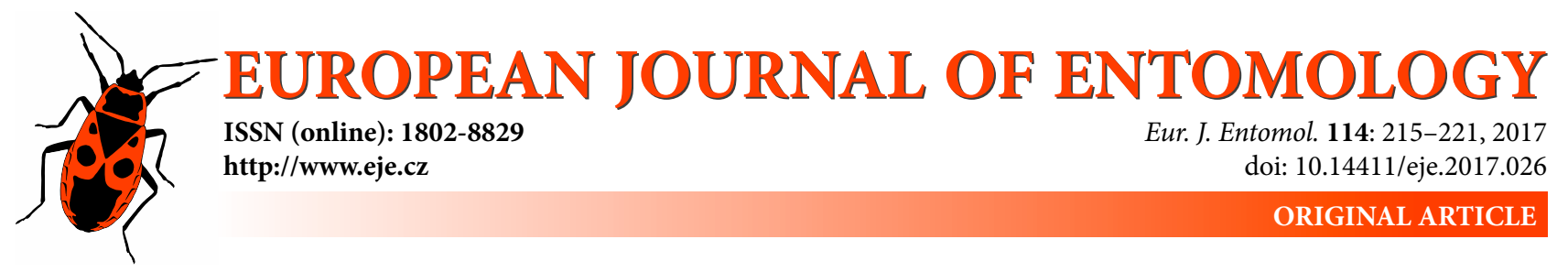

\title{
Do the arthropod communities on a parasitic plant and its hosts differ?
}

\author{
Alba LÁZARO-GONZÁLEZ, José A. HÓdAR and Regino ZAMORA \\ Departamento de Ecología, Facultad de Ciencias, Universidad de Granada, Avda. Fuentenueva s/n, E-18071 Granada, Spain; \\ e-mails: albalazaro@ugr.com, jhodar@ugr.es, rzamora@ugr.es
}

Key words. Mistletoe, Viscum album, hemiparasitic plant, pine host, Pinus, arthropod communities, specialist insect, Cacopsylla visci, Pinalitus viscicola, Anthocoris visci, Hemiptera

\begin{abstract}
Parasitic plants growing on tree branches may be a novel niche and phytoresource for arthropods. The spatial continuity between hosts and their parasites in canopies might provide a homogeneous environment for arthropod communities, but differences in mistletoe leaves and host needles could be exploited by different species of arthropods. Therefore, it is important to determine insect-community assemblages in order to discover the role of parasitic plants as a different habitat for arthropods. Thus, we aim to evaluate the level of similarity between the arthropod community on mistletoe (Viscum album) and that on its two principal pine hosts, Black pine (Pinus nigra) and Scots pine (P. sylvestris), on a Mediterranean mountain. Our results reveal that, irrespective of the species of pine host, $V$. album has a stable, independent and simple arthropod trophic web, composed mainly of two specialist hemipteran herbivores, Cacopsylla visci (Psyllidae) and Pinalitus viscicola (Miridae), and a hemipteran predator, Anthocoris visci (Anthocoridae). Despite this, the composition of the arthropod communities differed significantly on both host species, with a greater richness and diversity on Scots than Black pine and these differences are not reflected in the community on mistletoe. Overall, we conclude that, although Viscum album is considered to be a pest of pine, its presence increases the heterogeneity of the forest canopy by providing a novel habitat for a new and specific community of arthropods. In addition, this is a new record for and most probably an extension of the southernmost limit of the known geographical distribution of the arthropod community inhabiting $V$. album.
\end{abstract}

\section{INTRODUCTION}

Forest tree canopies are a heterogeneous environment, in which many traits (nitrogen content; leaf size, shape and toughness; and concentration of secondary compounds) vary widely and determine the foraging and behaviour of the resident arthropod community (Schultz, 1983). Taking advantage of this environmental heterogeneity a great diversity of organisms inhabit forest canopies, including thousands of species of plants, arthropods, vertebrates and microorganisms.

Mistletoes, a diverse group of hemiparasitic plants, inhabit forest canopies and take water as well as mineral resources from host plants, and are considered keystone species in forest ecosystems around the world (Watson, 2001; Watson \& Herring, 2012). By consuming plant resources, mistletoes are effectively functioning as herbivores (Pennings \& Callaway, 2002), with the important functional distinction that they can also compete with host plants for light. By doing so, mistletoes provide new pathways for plant-plant (Fisher et al., 2013; Graffis \& Kneitel, 2015) and plant-animal interactions in forest ecosystems (Watson, 2015; Mellado et al., 2016). For example, the presence of mistletoes growing on the branches of trees may introduce a novel niche within the canopy and increase the diversity of phytoresources for herbivores. In this respect, several herbivorous insects (Burns, 2009; Burns et al., 2014) and some mammals are reported as consumers of mistletoe foliage (e.g. Cooney et al., 2006; Umucalılar et al., 2007).

Because mistletoes are in intimate spatial association with the branches of their host, the spatial continuity of their photosynthetic tissues in canopies might foster a homogeneous distribution and abundance of the arthropod communities inhabiting both the host and the parasite. An alternative possibility is that the presence of mistletoes introduces an additional level of heterogeneity in a forest canopy, since both the physiology and morphology of mistletoe leaves and stems differ from those of its host plant (Těšitel et al., 2010). Consequently, on the one hand, hostdwelling arthropods might not be able to use the parasite as a new resource because of strong biochemical differences, which could nevertheless be exploited by a different arthropod species. This could result in different arthropod assemblages occurring on the host and the parasite. This is potentially a key scenario, since from the standpoint of the arthropods living on the parasite, the hemiparasitic plant may be an "ecological island" surrounded by an "unsuitable sea" of host canopy. 
In this study, we analyse this scenario using the mistletoe Viscum album ssp. austriacum as a case study. At the study site, a natural park in south-eastern Spain, mistletoe parasitizes almost exclusively two species of pine (López-Sáez \& Sanz de Bremond, 1992), Black and Scots pine (Pinus nigra ssp. salzmannii and $P$. sylvestris ssp. nevadensis, respectively). Black pine is a Mediterranean species and thus at our study site it should be at an optimum, while Scots pine has a Eurasian distribution and therefore at the site studied is a relict element from glaciations. Due to their distinct nature, these two host species could present different characteristics as resources for insect herbivores and therefore to have different arthropod communities.

Arthropod communities' on mistletoes are described in previous studies (Room, 1972; Tassone \& Majer, 1997; Anderson \& Braby, 2009; Burns et al., 2011). Of these, Burns et al. (2011) and Tassone \& Majer (1997) compare the arthropod communities' on mistletoes and their hosts in Australia at an ordinal level and restricted to the genus Psylloidea (Burns et al., 2014). In addition, the community assemblage on Viscum album is described at the species level in Central (Zuber, 2004; Hellrigl, 2006; Briggs, 2011; Varga et al., 2012) and Northern Europe (Hansen \& Hodkinson, 2006; Struwe et al., 2009), but parallel studies on the arthropod communities on their hosts are lacking. Thus, this is the first comparative study of a community assemblage at a higher taxonomic resolution in terms of the composition of arthropods inhabiting Viscum album and its host, pine trees.

In this respect, the question we seek to answer is which of these two forces, the "spatial intimacy" or "mistletoespine taxonomic differentiation in terms of vegetal tissues", is the stronger. Our hypothesis is that tissue differentiation should be more important than the spatial privacy settings of arthropod communities, so we expect mistletoes to have a singular arthropod community of specialist insects, irrespective of the host species. In this study, we explore the arthropod community associated with the two host species and the parasite, focusing on the abundance, species richness, the herbivore-predator ratio $(\mathrm{H}: \mathrm{P}$ ratio), Shannon Index (H') and composition of arthropod communities.

\section{MATERIALS AND METHODS}

\section{Study site}

Mistletoe Viscum album ssp. austriacum (Wiesb.) Vollman is a dioecious parasitic plant native to the European region, which throughout its distribution specializes in parasitizing conifers, mainly species of Pinus (Zuber, 2004). This study was conducted in the Natural Park of Sierra de Baza, Granada (a subregion of Sierras Penibéticas Septentrionales, south-eastern Spain, $2^{\circ} 51^{\prime} 48^{\prime \prime} \mathrm{W}, 37^{\circ} 22^{\prime} 57^{\prime \prime} \mathrm{N}, 1650 \mathrm{~m}$ a.s.1.), which is at the southernmost limit of the geographical distribution of mistletoe (Zuber, 2004). The climate at the site is typically Mediterranean, with an annual mean temperature of $15.5^{\circ} \mathrm{C}$ and annual mean rainfall of $307 \mathrm{~mm}$ (CMAOT 2015), concentrated in autumn and spring, and with hot and dry summers (June-September) followed by cold winters (December-March). Conifers are the dominant forest vegetation ( $43 \%$ of the total surface coverage) and Black (Pinus nigra Arn. ssp. salzmannii) and Scots (P. sylvestris L.) pine are the main host species of mistletoe although there are other species of pine present, such as Aleppo (P. halepensis Mill.) and Maritime (P. pinaster Ait.) pine, as well as oaks (Quercus ilex L., 9\%) and shrubland (23\%) (CMAOT 2008).

\section{Sampling}

Plants were sampled in August 2012. Since our interest was focused on the differences between the arthropods living on mistletoe and their hosts, we selected midsummer because it is when arthropods are most active. Furthermore, at this time the new leaves on both mistletoe and pine are fully developed, and both plants are metabolically active (Lázaro-González, unpubl.).

We selected 10 Black and 10 Scots pines with similar parasitic loads $(30-50 \%$ of the tree canopy consisted of mistletoe). For each pine selected, we recorded tree height and $\mathrm{DBH}$, and chose an adult mistletoe plant (35-90 cm in diameter, corresponding to individuals $>9$ years old), which was placed in a bag in situ. Quickly, we cut and sprayed the mistletoe inside the bag with pyrethroid insecticide (Coopermatic ${ }^{\circledR}$ with pure natural pyrethrins: $1.67 \%$ and piperonyl butoxide: $11.10 \%$ ). On the opposite side of the tree, we chose and sampled the apical portion of a live pine branch, including needles and shoots, which was not infected with mistletoe but of a similar size to the mistletoe sample, following the same procedure.

Pine branches and mistletoe plants were then quickly taken to a laboratory and processed. Bags with samples inside were carefully shaken above a tray to separate the arthropods. Arthropods were identified to the lowest taxonomic level, counted to determine the total abundance for each taxonomic level, classified according to trophic level (herbivores and predators), and stored in vials with Scheerpeltz. Then, pine branches and mistletoes were measured, recording their wet weight, basal diameter, length, width, age and sex for mistletoes, and height and DBH for pine trees (Appendix 1). Hereafter, abundance refers to the number of insects divided by either the wet weight of pine branches or mistletoe plants, and thus abundance is a corrected sample-size value and comparable between samples. The $\mathrm{H}: \mathrm{P}$ ratio was calculated as the herbivore abundance divided by predator abundance. Species richness is the total number of different taxonomic groups identified.

\section{Statistical analyses}

Generalized Linear Mixed Models (GLMM's) were used to test host species (Black or Scots pine) and vegetal-tissue effects (mistletoe leaves or pine needles) on species richness and the $\mathrm{H}: \mathrm{P}$ ratio of the arthropod community, assuming a Poisson distribution of data and tree as a random factor.

Linear Mixed Models (LMM) were used to test the host species and tissue effects (fixed factors) on abundance and Shannon index, assuming tree as a random factor. Abundance and the Shannon Index were log transformed, and all model assumptions were tested.

All statistical analyses were done using R software, Version 3.2.1 (R development Core Team, 2015). GLMM and LMM's were implemented in the glmer and lmer function of the lmerTest package. Shannon index was calculated using the diversity function in the vegan package.

Multivariate analyses were used to test differences in arthropod composition between mistletoe plants parasitizing Black and Scots pine, and between the branches of both these hosts. Firstly, samples were ordered using Non-metric MultiDimensional Scaling (nMDS) based on the Bray-Curtis similarity distances using the vegdist function. Then, an analysis of similarity (ANOSIM), based on 10,000 permutations, was used to establish significant differences in arthropod abundance depending on host species $(P$. nigra or P. sylvestris) and plant tissue (pine or mistletoe) using the anosim function. ANOSIM returns $R$ values that can vary from 0 

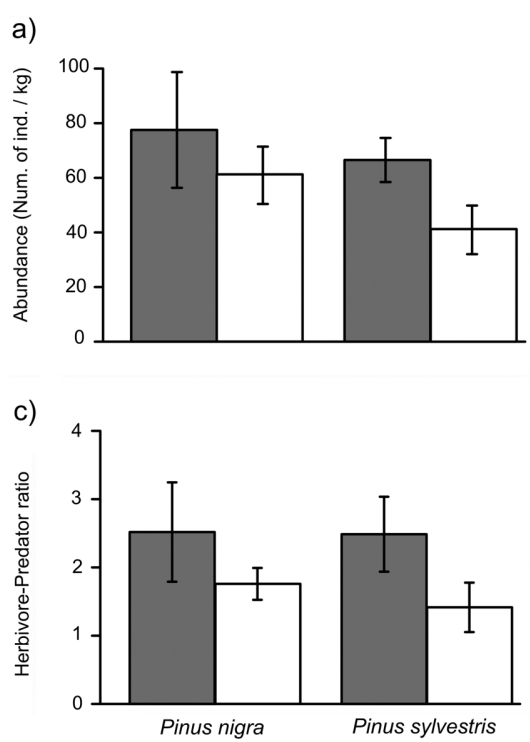

b)
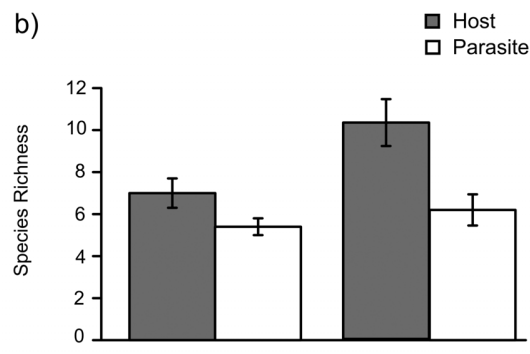

d)

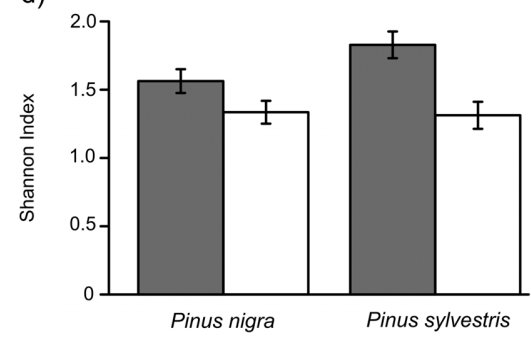

Fig. 1. Mean ( \pm SE) of a) abundance, b) species richness, c) H:P ratio and d) Shannon index of arthropod communities associated with two species of pine (grey bars) and their parasite Viscum album (white bars).

(similar communities between groups) to 1 (big differences in the communities between groups), and $P$-values that are significance levels. Finally, the taxonomic groups that most contributed to differences in assemblage composition were identified by similarity percentages (SIMPER). Vegdist, anosim and simper functions are included in the vegan package. NMDS was used to determine the composition of the assemblages from databases, using the last matrix distance and isoMDS function in the MASS package.

Throughout the paper, means are expressed $\pm 1 \mathrm{SE}$.

\section{RESULTS}

\section{Abundance, species richness, $\mathrm{H}$ : $\mathrm{P}$ ratio, and Shannon index of the arthropod communities}

A total of 1271 arthropods were collected, which included individuals belonging to 12 orders and 33 taxonomic groups (Appendix 2). The arthropod communities on mistletoes and their host pine differed in terms of all the aspects tested (Table 1), although no significant interactions were found between host species and plant tissue. Although a significantly greater species richness and diversity was recorded on Scots pines (29 taxonomic groups and $\left.H^{\prime}=1.82 \pm 0.1\right)$ than on Black pines (18 taxonomic groups and $\left.H^{\prime}=1.56 \pm 0.1\right)$, mistletoes consistently had the same richness on both hosts, with 18 and 16 taxonomic groups, $H^{\prime}=1.31 \pm 0.1$ and $H^{\prime}=1.330 .1$, respectively. The average abundance of arthropods and their $\mathrm{H}$ : $\mathrm{P}$ ratio were significantly greater for the communities inhabiting pine trees $(72.0 \pm 11.1$ arthropods $/ \mathrm{kg}$ and $2.5 \pm 0.4)$ than mistletoe $(51.2 \pm 7.1$ arthropods $/ \mathrm{kg}$ and $1.6 \pm 0.2)$. Overall, pines had higher richness, abundance, $\mathrm{H}: \mathrm{P}$ ratio and diversity than mistletoe (Fig. 1).

All these results imply that Scots pine has a richer and more diverse arthropod community than Black pine but similar abundance and $\mathrm{H}: \mathrm{P}$ ratio; however, these differences are not reflected in the arthropod community on mistletoe, which is composed of fewer species with a lower abundance and diversity than that recorded on pines.

\section{Composition of the arthropod communities}

The compositions of the arthropod communities recorded on mistletoe and its hosts (Fig. 2) were highly significantly different for both host species, based on the $R$ and $P$ value, respectively $\left(\right.$ ANOSIM $_{P \text {. nigra }}: \mathrm{R}=0.885, \mathrm{P}<0.001$; ANOSIM $\left._{P_{\text {. sylvestris }}}: \mathrm{R}=0.999, \mathrm{P}<0.001\right)$.

Although the only significant differences between hosts were species richness and diversity, these analyses reveal that there were also fewer differences in the arthropod communities on Black and Scots pine (ANOSIM HоsтS, $_{\text {, }}$ $\mathrm{R}=0.212, \mathrm{P}<0.001)$. The SIMPER analysis revealed that these differences are attributable principally to psyllids, which were three times more abundant on Scots pine $(20.46 \pm 3.04$ individuals $/ \mathrm{kg})$ than on Black pine $(7.21 \pm$ 1.90 individuals $/ \mathrm{kg}$ ). Spiders and thrips were also twice as abundant on Black $(21.56 \pm 7.29$ and $15.46 \pm 9.98$ individuals $/ \mathrm{kg}$, respectively) than on Scots pine (12.36 \pm 1.97 and $6.24 \pm 2.61$ individuals $/ \mathrm{kg}$, respectively) and aphids were abundant on Black (14.82 \pm 8.13 individuals $/ \mathrm{kg})$ but practically absent on Scots pine $(0.91 \pm 0.50$ individuals/

Table 1. The effect of host species ( $P$. nigra and $P$. sylvestris), vegetal tissue (mistletoe leaves and pines needles) and their interaction on the abundance, richness of species, herbivore-predator ratio and diversity of arthropod communities. $\chi^{2}, F$-values, significance $(P)$ and degrees of freedom (df) come from the GLMM and LMM ${ }_{A N O V A}$ tables. Bold type indicate significant results.

\begin{tabular}{|c|c|c|c|c|c|c|c|c|c|c|c|c|}
\hline & \multicolumn{3}{|c|}{ Abundance } & \multicolumn{3}{|c|}{ Richness } & \multicolumn{3}{|c|}{$\mathrm{H}: \mathrm{P}$ ratio } & \multicolumn{3}{|c|}{ Shannon index } \\
\hline & $\mathrm{df}$ & $F$ & $P$ & $\mathrm{df}$ & $\chi^{2}$ & $P$ & $\mathrm{df}$ & $\chi^{2}$ & $P$ & $\mathrm{df}$ & $F$ & $P$ \\
\hline Host species & 1,18 & 0.53 & 0.473 & 1 & 5.34 & 0.021 & 1 & 0.01 & 0.917 & 1,18 & 0.49 & 0.491 \\
\hline Vegetal tissue & 1,18 & 3.29 & 0.086 & 1 & 10.95 & $<0.001$ & 1 & 3.99 & 0.046 & 1,18 & 25.46 & $<0.001$ \\
\hline Interaction & 1,18 & 2.99 & 0.101 & 1 & 1.05 & 0.306 & 1 & 0.20 & 0.635 & 1,18 & 3.51 & 0.077 \\
\hline
\end{tabular}




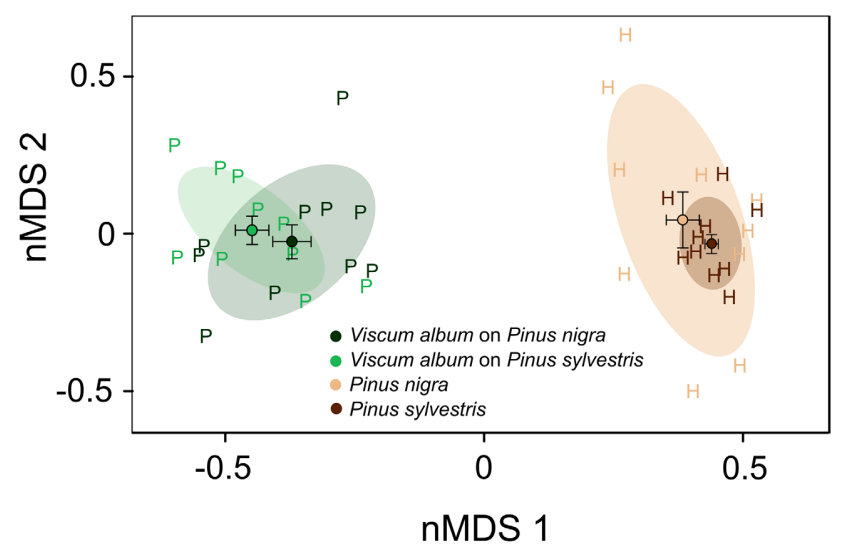

Fig. 2. Non-Metric MultiDimensional Scaling (nMDS) ordination of arthropod communities recorded on mistletoe $(P=$ dark green on $P$. nigra and light green on $P$. sylvestris) and their hosts $(\mathrm{H}=$ light brown on $P$. nigra and dark brown on $P$. sylvestris). Points are means $( \pm$ SE) of the distributions of the compositions of arthropods inhabiting mistletoe and its hosts.

$\mathrm{kg}$ ). The aphids were Cinara pini and Eulachnus sp. (Hemiptera: Sternorrhyncha).

The composition of the arthropod community on mistletoe plants parasitizing both host plants was similar (ANO$\left.\mathrm{SIM}_{\text {PARASITES }}, \mathrm{R}=0.105, \mathrm{P}=0.069\right)$. These similarities were due to the mistletoe bug, Pinalitus cf. viscicola, the sap-sucking bug, Cacopsylla cf. visci, and their predator, Anthocoris $c f$. visci, making up 79\% and spiders $8 \%$ of the arthropod assemblage on mistletoes. These results closely fit the preceding results, since the host and parasite differed in all variables tested as well as in the composition of the arthropod communities, while the arthropod community on mistletoe remained constant despite those on Scots and Black pines differing in richness, diversity and relative abundance.

The Global SIMPER analysis also revealed that the main differences recorded between mistletoe and its hosts were attributable to three main taxa: Cacopsylla visci (19\% of total contribution), Anthocoris visci (15\%) and Pinalitus viscicola $(5 \%)$, which clearly accounted for more of the arthropods on mistletoe $(19.45 \pm 3.84,15.66 \pm 2.90$ and 5.21 \pm 1.60 individuals $/ \mathrm{kg}$, respectively) than on pine trees $(0.0$ $\pm 0.0,0.29 \pm 0.25$ and $0.07 \pm 0.07$ individuals $/ \mathrm{kg}$, respectively both pine species merged). Other arthropods such as Psyllidae, Araneae and Thysanoptera were also responsible for these differences (contributing 14\%, 12\% and $8 \%$, respectively), but there were more psyllids, spiders and thrips on pine trees $(13.84 \pm 2.31,16.96 \pm 3.83$ and 10.65 \pm 5.13 individuals $/ \mathrm{kg}$, respectively) than on mistletoe $(0.0$ $\pm 0.0,4.25 \pm 1.07$ and $0.27 \pm 0.22$ individuals $/ \mathrm{kg}$, respectively) where they were practically absent.

\section{DISCUSSION}

The arthropod community on $V$. album is well studied and there are several host specific insects associated with this plant in Central Europe (Hellrigl, 2006; Briggs, 2011; Varga et al., 2012; Schumacher, 1918 in Zuber, 2004). In addition, some studies on arthropod assemblages support the contention of a high degree of host specificity of the psyllids on European mistletoe (Hansen \& Hodkinson, 2006; Struwe et al., 2009) and other species of mistletoes (Whittaker, 1982; Burns \& Watson, 2013). However, there are a few direct comparisons of the arthropod communities on mistletoes and their hosts that are restricted to the Psylloidea (Burns et al., 2014) or an ordinal level of taxonomic resolution, which record finding the same arthropod orders on both mistletoes and their hosts (Tassone \& Majer, 1997; Burns et al., 2011), but that the total abundance is greater on the foliage of the host (Burns et al., 2011).

By contrast, our study provides detailed information on all the arthropod species at a fine taxonomic resolution living on both mistletoe and its host plants; the results reveal clear differences between the arthropod communities associated with two species of pines (Pinus nigra and $P$. sylvestris) and their shared parasitic plant (Viscum album ssp. austriacum).

The arthropod community on $P$. sylvestris is significantly richer, more diverse and different in composition than that on P. nigra (relative abundances of psyllids on Scots pine and spiders, thrips and aphids on Black pine), probably due to the distinct nature of these two species. Despite these differences the mistletoe parasitizing them harbour a simpler and specific arthropod community, consisting of two herbivores and their predator, and a lower abundance itinerant spiders (Burns \& Watson, 2013). The herbivores are Cacopsylla visci and Pinalitus viscicola, which are recorded inhabiting $V$. album across Europe (Zuber, 2004; Hansen \& Hodkinson, 2006; Struwe et al., 2009; Varga et al., 2012) and their main predator Anthocoris visci (Hellrigl, 2006; Briggs, 2011). In line with this, the arthropod community recorded on $V$. album in these studies there are 8 host specific insects inhabiting mistletoes in Hungary (Varga et al., 2012) and northern Italy (Hellrigl, 2006), 6 in England (Briggs, 2011), 5 in France (Schumacher, 1918 in Zuber, 2004) and a few less (minimum 3 ) in Sweden (Struwe et al., 2009). Thus, the results of our study indicates that V. album in Southern Europe has a simpler community than mistletoe in the rest of Europe (Zuber, 2004; Hellrigl, 2006; Briggs, 2011; Varga et al., 2012), given that we recorded only three insect mistletoe specialists. In addition, the present study enlarges the distribution of these insects, with most probably a new southern limit to the distribution of $C$. visci, $P$. viscicola and $A$. visci. The most important difference in the composition (Fig. 2) of arthropod assemblages between hosts and parasite was due to the high specificity of these three species for mistletoe; while the arthropods restricted to pine are pine-feeding herbivores (e.g. thrips, psyllids, leafhoppers, aphids) that are unable to use mistletoe as a resource. In addition, other arthropods are canopy generalists, and opportunistically occur on mistletoe when seeking food and/or shelter (Burns \& Watson, 2013). In line with this, the arthropod assemblage on mistletoe is similar in abundance, species richness, $\mathrm{H}: \mathrm{P}$ ratio and diversity, irrespective of the host species. Our results are consistent with the general pattern (Pimm, 1991) in which communities with many predators and prey species, as those on pine trees have high $\mathrm{H}: \mathrm{P}$ ratios. 
Even though the "spatial intimacy" in terms of the close contact between mistletoe and the branches of their host may seem to provide spatial continuity in tree canopy, the arthropods associated with mistletoe avoid pine needles and branches and vice versa. This supports the hypothesis that the mistletoe-pine taxonomic differentiation in vegetal tissue is a stronger force than is spatial intimacy.

Despite the fact that Viscum album is traditionally considered to be a pest of its pine hosts (Muñoz et al., 2008; Sangüesa-Barreda et al., 2012) it increases the heterogeneity of the forest canopy by providing a novel habitat for a new and specific community of arthropods. This additional level of heterogeneity in a forest canopy increases the arthropod diversity and spatial range for some insects, by providing mistletoes a new ecological value. Arthropods are the most diverse and numerous of all living animals, a major part of the global biodiversity and important components of ecosystems (New, 1998; Weisser \& Siemann, 2004). By contrast, arthropods are usually overlooked by policy makers and the conservation community (Cardoso et al., 2011). Only 1268 insect species are included in the 2016 IUCN "Red List of Threatened Species", which includes a total of 12630 animals $(65 \%$ of them vertebrates; IUCN, 2016). In Spain, a total of 617 species or subspecies are catalogued as threatened, of which only 116 are arthropods (IUCN, 2016), undoubtedly mainly due to a lack of information. This work clearly exemplifies the mismatch between considering mistletoe as a pest that needs to be controlled vs. a keystone species providing new opportunities for novel species (Mellado \& Zamora, 2015; Mellado et al., 2016).

In summary, Viscum album in Southern Europe has a stable, independent and the simplest arthropod community in Europe. For this parasitic plant, Cacopsylla visci and Pinalitus viscicola are the only two specialist herbivores, and Anthocoris visci the only specialist predator, which probably at this location are at the southernmost limit of their geographical distribution. Thus, mistletoe parasitizing pine is not in spatial continuity in terms of the distribution and abundance of arthropod communities between parasite and host. Therefore, this parasitic plant represents isolated patches surrounded by the foliage of its host, inhabited by only a few insects specific to mistletoe. In short, Viscum album determines the presence of particular specific insects by providing an ecological island in a sea of host foliage and as such is a keystone species for a unique and specialized trophic web.

ACKNOWLEDGMENTS. The Andalusian Environmental Council, Junta de Andalucía and the Directors of the Sierra de Baza Natural Park provided permission for field work. R. Ruiz-Puche helped us with field sampling and laboratory processing of samples. D. Nesbitt checked the English version of this manuscript. This study was supported by project CLAVINOVA CGL201129910 from the Spanish Ministry of Science and Innovation (MICINN), and a FPI predoctoral grant from MCYT to ALG. The authors would like to thank an anonymous reviewer and the editor S.T. Segar for their comments and suggestions that improved this manuscript. JAH and RZ conceived and designed the study.
JAH, RRP and ALG collected the data, ALG analysed the data and all authors wrote and revised the manuscript.

\section{REFERENCES}

ANDERSON S.J. \& BRABy M.F. 2009: Invertebrate diversity associated with tropical mistletoe in a suburban landscape from northern Australia. - North. Territ. Nat. 21: 2-23.

Briggs J. 2011: Mistletoe (Viscum album): A brief review of its local status with recent observations on its insects associations and conservation problems. - Proc. Cotteswold Natur Fld Club 45: 181-193.

BuRns A.E. 2009: Diversity and Dynamics of the Arthropod Assemblages Inhabiting Mistletoe in Eucalypt Woodlands. $\mathrm{PhD}$ thesis, Charles Sturt University, Albury-Wodonga, Australia.

BuRns A.E. \& WATSON D.M. 2013: Islands in a sea of foliage: Mistletoes as discrete components of forest canopies. In Lowman M. (ed.): Treetops at Risk: Challenges of Global Canopy Ecology and Conservation. Springer, New York, pp. 215-222.

Burns A.E., Cunningham S.A. \& Watson D.M. 2011: Arthropod assemblages in tree canopies: a comparison of orders on box mistletoe (Amyema miquelii) and its host eucalypts. - Austral. J. Entomol. 50: 221-230.

Burns A.E., TaYlor G.S., Watson D.M. \& Cunningham S.A. 2014: Diversity and host specificity of Psylloidea (Hemiptera) inhabiting box mistletoe, Amyema miquelii (Loranthaceae) and three of its host Eucalyptus species. - Austral. Entomol. 54: 306-314.

Cardoso P., Erwin T.E., Borges P.A.V. \& New T.R. 2011: The seven impediments in invertebrate conservation and how to overcome them. - Biol. Conserv. 144: 2647-2655.

CMAOT 2008: Usos del suelo y coberturas vegetales en Andalucía, por Espacio Natural Protegido, 2007. Consejería de Medio Ambiente y Ordenación del Territorio, Junta de Andalucía. URL: www.juntadeandalucia.es/medioambiente/web/ Bloques_Tematicos/Estadisticas_e_Indicadores/Estadisticas_ Oficiales_de_la_Consejeria_de_Medio_Ambiente/SueloUso/ usoscob_enp--2007.xls.

CMAOT 2015: Temperaturas et precipitaciones medias anuales en grandes áreas geográficas de Andalucia, 1995-2015. Consejería de Medio Ambiente y Ordenación del Territorio, Junta de Andalucía. URL: http://www.juntadeandalucia.es/medioambiente/vem/?c=Menu/tema/283.

Cooney S.J., Watson D.M. \& Young J. 2006: Mistletoe nesting in Australian birds: a review. - Emu 106: 1-12.

Fisher J.P., Phoenix G.K., Childs D.Z., Press M.C., Smith S.W., Pilkington M.G. \& Cameron D.D. 2013: Parasitic plant litter input: a novel indirect mechanism influencing plant community structure. - New Phytol. 198: 222-231.

Graffis A.M. \& KNeITEL J.M. 2015: A parasitic plant increases native and exotic plant species richness in vernal pools. $-A o B$ Plants 7: plv100, $10 \mathrm{pp}$.

HANSEN L.O. \& Hodkinson I.D. 2006: The mistletoe associated psyllid Cacopsylla visci (Curtis, 1835) (Homoptera, Psyllidae) in Norway. - Norw. J. Entomol. 53: 89-91.

Hellrigl K. 2006: Untersuchungen über Insekten der Misteln in Südtirol (Viscum album: Loranthaceae). - Forest Observer 2/3: 43-68.

IUCN 2016: 2016 IUCN Red List Summary Statistics. URL: http://www.iucnredlist.org/about/summary-statistics.

López SÁez J.A. \& SAnz de Bremond C. 1992: Viscum album L. y sus hospedantes en la Península Ibérica. - Bol. Sanid. Veget. Plagas 18: 817-825.

Mellado A., Morillas L., Gallardo A. \& Zamora R. 2016: Temporal dynamic of parasite-mediated linkages between the 
forest canopy and soil processes and the microbial community. — New Phytol. 211: 1382-1392.

Mellado A. \& Zamora R. 2015: Spatial heterogeneity of a parasitic plant drives the seed-dispersal pattern of a zoochorous plant community in a generalist dispersal system. - Funct. Ecol. 20: 459-467.

Muñoz C., Pérez V., Cobos P., Hernández R. \& SÁnchez G. 2007: Viscum album L. 1753. In Sanidad forestal: Guía en imágenes de plagas, enfermedades y otros agentes presentes en los bosques. 2nd ed. Mundi-Prensa, Madrid, pp. 458-459.

New T.R. 1998: Invertebrate Surveys for Conservation. Oxford University Press, New York, 252 pp.

Pennings S.C. \& Callaway R.M. 2002: Parasitic plants: parallels and contrasts with herbivores. - Oecologia 131: 479-489.

PImm S.L. 1991: The Balance of Nature? Ecological Issues in the Conservation of Species and Communities. University of Chicago Press, Chicago, 448 pp.

R DeVelopment Core TeAm 2015: R: A Language and Environment for Statistical Computing. R Foundation for Statistical Computing, Vienna.

Room P.M. 1972: The constitution and natural history of the fauna of the mistletoe Tapinanthus bangwensis (Engl. \& K. Krause) growing on cocoa in Ghana. - J. Anim. Ecol. 41: 519-535.

Sangüesa-Barreda G., Linares J.C. \& Camarero J.J. 2012: Mistletoe effects on Scots pine decline following drought events: insights from within-tree spatial patterns, growth and carbohydrates. - Tree Physiol. 32: 585-598.

Schultz J.C. 1983: Habitat selection and foraging tactics of caterpillars in heterogeneous trees. In Denno R.F. \& McClure M.S. (eds): Variable Plants and Herbivores in Natural and Managed Systems. Academic Press, New York, pp. 61-90.

Struwe I., Gertsson C.A. \& Coulianos C.C. 2009: [Insects monophagous on mistletoe (Viscum album L.) newly discovered in Sweden: Cacopsylla visci (Curtis, 1835) (Hemiptera, Psyllidae) and Pinalitus viscicola (Puton, 1888) (Hemiptera,
Miridae).] — Entomol. Tidskr. 130: 155-160 [in Swedish, English abstract].

TASSONE R.A. \& MAJER J.D. 1997: Abundance of arthropods in tree canopies of Banksia woodland on the Swan Coastal Plain. - J. R. Soc. West. Aust. 80: 281-286.

TéŠitel J., Plavcová L. \& Cameron D.D. 2010: Interactions between hemiparasitic plants and their hosts: the importance of organic carbon transfer. - Plant Signal. Behav. 5: 1072-1076.

Umucalilar H.D., Gülşen N., Coşkun B., Hayirli A. \& Dural H. 2007: Nutrient composition of mistletoe (Viscum album) and its nutritive value for ruminant animals. - Agrofor. Syst. 71: 77-87.

Varga I., Keresztes B. \& Poczai P. 2012: Data to the Hungarian insect fauna of European mistletoe (Viscum album). - Növényvédelem 4: 153-164.

Watson D.M. 2001: Mistletoe - A keystone resource in forests and woodlands worldwide. - Annu. Rev. Ecol. Syst. 32: 219249.

Watson D.M. 2015: Disproportionate declines in ground-foraging insectivorous birds after mistletoe removal. - PloS ONE 10(12): e0142992, 12 pp.

Watson D.M. \& Herring M. 2012: Mistletoe as a keystone resource: an experimental test. - Proc. R. Soc. Lond. (B) 279: 3853-3860.

Weisser W.W. \& Siemann E. 2004: The various effects of insects on ecosystem functioning. In Weisser W.W. \& Siemann E. (eds): Insects and Ecosystem Function. Springer, Berlin, Heidelberg, pp. 3-24.

WhitTAKer P.L. 1982: Community Ecology of Phoradendron tomentosum in Southern Texas. PhD Thesis, University of Texas at Austin, $122 \mathrm{pp}$.

ZUBER D. 2004: Biological flora of Central Europe: Viscum album L. - Flora 199: 181-203.

Received December 19, 2016; revised and accepted March 14, 2017 Published online April 12, 2017

Appendix 1. Details of the measurements of mistletoe plants $(A)$ and pine tree host branches (B) collected from Black pine $(n=10)$ and Scots pine $(n=10)$.

\begin{tabular}{|c|c|c|c|c|c|c|c|}
\hline \multicolumn{8}{|c|}{ A) Mistletoe plants } \\
\hline Id & Host species & Wet weight $(\mathrm{kg})$ & Basal diameter $\left(\mathrm{mm}^{2}\right)$ & Length $(\mathrm{cm})$ & Width $(\mathrm{cm})$ & Sex & Age (years) \\
\hline 1 & \multirow{10}{*}{ Pinus nigra } & 0.30 & $14.90 \times 16.70$ & 32 & 45 & Female & 10 \\
\hline 2 & & 0.28 & $20.60 \times 19.00$ & 35 & 35 & Female & 9 \\
\hline 3 & & 1.10 & $23.40 \times 28.60$ & 48 & 80 & Male & 16 \\
\hline 4 & & 0.30 & $15.40 \times 14.50$ & 34 & 37 & Female & 9 \\
\hline 5 & & 0.17 & $15.80 \times 20.42$ & 30 & 33 & Female & 10 \\
\hline 6 & & 0.27 & $14.54 \times 15.62$ & 29 & 46 & Male & 10 \\
\hline 7 & & 0.22 & $17.75 \times 15.17$ & 37 & 35 & Female & 9 \\
\hline 8 & & 0.23 & $13.57 \times 15.72$ & 42 & 51 & Female & 11 \\
\hline 9 & & 0.59 & $27.98 \times 23.91$ & 49 & 56 & Male & 14 \\
\hline 10 & & 0.31 & $26.98 \times 21.71$ & 51 & 47 & Female & 23 \\
\hline 11 & \multirow{10}{*}{ Pinus sylvestris } & 3.45 & $52.10 \times 42.40$ & 98 & 65 & Female & 24 \\
\hline 12 & & 0.58 & $31.98 \times 24.62$ & 43 & 63 & Female & 14 \\
\hline 13 & & 3.04 & $31.40 \times 44.20$ & 120 & 67 & Female & 30 \\
\hline 14 & & 0.90 & $19.40 \times 23.60$ & 58 & 60 & Male & 19 \\
\hline 15 & & 0.87 & $25.00 \times 30.00$ & 49 & 55 & Female & 20 \\
\hline 16 & & 0.14 & $15.48 \times 16.19$ & 30 & 42 & Female & 11 \\
\hline 17 & & 0.23 & $19.85 \times 17.85$ & 49 & 50 & Female & 14 \\
\hline 18 & & 0.37 & $20.54 \times 19.30$ & 32 & 65 & Female & 15 \\
\hline 19 & & 1.39 & $39.64 \times 32.34$ & 102 & 88 & Female & 21 \\
\hline 20 & & 0.55 & $17.21 \times 17.01$ & 70 & 67 & Female & 9 \\
\hline
\end{tabular}




\begin{tabular}{|c|c|c|c|c|c|c|c|}
\hline \multicolumn{8}{|c|}{ B) Pine tree host branches } \\
\hline Id & Host species & Wet weight $(\mathrm{kg})$ & Basal diameter $\left(\mathrm{mm}^{2}\right)$ & Length (cm) & Width (cm) & Height tree $(\mathrm{m})$ & $\mathrm{DBH}$ tree $(\mathrm{cm})$ \\
\hline 1 & \multirow{9}{*}{ Pinus nigra } & 0.40 & $16.00 \times 16.80$ & 75 & 43 & 8.1 & 117 \\
\hline 2 & & 0.47 & $18.90 \times 19.80$ & 70 & 40 & 8.1 & 155 \\
\hline 3 & & 0.71 & $22.70 \times 21.70$ & 150 & 60 & 7.7 & 95 \\
\hline 4 & & 0.31 & $16.22 \times 16.06$ & 52 & 57 & 5.9 & 92 \\
\hline 5 & & 0.26 & $17.40 \times 17.81$ & 66 & 54 & 8.5 & 89 \\
\hline 6 & & 0.24 & $15.71 \times 14.42$ & 50 & 33 & 6.8 & 71 \\
\hline 7 & & 0.18 & $12.41 \times 12.33$ & 66 & 37 & 4.7 & 50 \\
\hline 8 & & 0.25 & $14.46 \times 15.20$ & 58 & 41 & 7.2 & 56 \\
\hline 9 & & 0.59 & $21.59 \times 21.54$ & 96 & 87 & 7.2 & 115 \\
\hline 10 & \multirow{11}{*}{ Pinus sylvestris } & 0.47 & $16.67 \times 15.45$ & 100 & 58 & 9.4 & 138 \\
\hline 11 & & 1.15 & $21.20 \times 21.40$ & 85 & 60 & 7.2 & 125 \\
\hline 12 & & 0.48 & $19.04 \times 19.29$ & 59 & 40 & 9.9 & 124 \\
\hline 13 & & 1.33 & $25.70 \times 26.10$ & 98 & 63 & 9.0 & 105 \\
\hline 14 & & 0.71 & $19.00 \times 19.00$ & 70 & 35 & 6.3 & 118 \\
\hline 15 & & 0.76 & $21.08 \times 20.01$ & 85 & 60 & 7.2 & 112 \\
\hline 16 & & 0.19 & $17.47 \times 14.67$ & 48 & 25 & 7.2 & 120 \\
\hline 17 & & 0.64 & $20.80 \times 20.55$ & 96 & 53 & 7.2 & 145 \\
\hline 18 & & 0.34 & $16.19 \times 15.73$ & 73 & 51 & 8.5 & 149 \\
\hline 19 & & 1.10 & $25.86 \times 5.64$ & 99 & 51 & 8.9 & 138 \\
\hline 20 & & 0.55 & $18.87 \times 18.57$ & 91 & 51 & 8.9 & 138 \\
\hline
\end{tabular}

Appendix 2. Taxonomic composition (at the ordinal, subordinal, family, subfamily, genus and species level), trophic level and relative abundance of the arthropods communities on mistletoe and its hosts ( $n=10$ for each host species).

\begin{tabular}{|c|c|c|c|c|c|c|}
\hline \multirow[t]{2}{*}{ Order } & \multirow[t]{2}{*}{ Taxonomic group } & \multirow[t]{2}{*}{ Trophic level } & \multicolumn{2}{|c|}{$\begin{array}{c}\text { Community } \\
\text { inhabiting mistletoe }\end{array}$} & \multicolumn{2}{|c|}{$\begin{array}{c}\text { Community } \\
\text { inhabiting pines }\end{array}$} \\
\hline & & & P. nigra & P. sylvestris & P. nigra & P. sylvestris \\
\hline Coleoptera & SubFam. Alticinae & Herbivour & 3.5 & 3.3 & 0.0 & 1.4 \\
\hline Hemiptera & Cacopsylla visci & Herbivour & 42.1 & 32.0 & 0.0 & 0.0 \\
\hline Hemiptera & Cinara pini & Herbivour & 0.5 & 0.0 & 10.2 & 0.3 \\
\hline Hemiptera & Fam. Coreidae & Herbivour & 0.0 & 0.0 & 0.7 & 0.4 \\
\hline Coleoptera & Fam. Curculionidae & Herbivour & 0.4 & 0.0 & 0.0 & 0.5 \\
\hline Hemiptera & Eulachnus sp. & Herbivour & 0.0 & 0.0 & 8.9 & 1.1 \\
\hline Hemiptera & Holcogaster sp. & Herbivour & 0.0 & 0.0 & 2.4 & 0.8 \\
\hline Hemiptera & Fam. Cicadellidae & Herbivour & 1.7 & 0.9 & 6.2 & 12.1 \\
\hline Lepidoptera & Lepidoptera larvae & Herbivour & 0.5 & 0.0 & 0.5 & 0.1 \\
\hline Hemiptera & Ligaeus militaris & Herbivour & 0.0 & 0.0 & 0.7 & 0.8 \\
\hline Hemiptera & Fam. Margarodidae & Herbivour & 0.0 & 0.0 & 0.0 & 0.2 \\
\hline Hemiptera & SuperFam. Miroidea & Herbivour & 0.0 & 0.0 & 1.2 & 2.2 \\
\hline Hemiptera & Pinalitus viscicola & Herbivour & 8.7 & 12.4 & 0.0 & 0.2 \\
\hline Hemiptera & Fam. Psyllidae & Herbivour & 0.0 & 0.0 & 9.3 & 30.8 \\
\hline Thysanoptera & Fam. Thripidae & Herbivour & 0.0 & 1.3 & 20.0 & 9.4 \\
\hline Hemiptera & Anthocoris visci & Predator & 27.6 & 35.2 & 0.6 & 0.1 \\
\hline Araneae & O. Araneae & Predator & 9.1 & 7.1 & 27.8 & 18.6 \\
\hline Coleoptera & Fam. Carabidae & Predator & 0.9 & 0.3 & 0.0 & 0.4 \\
\hline Coleoptera & Fam. Coccinelidae & Predator & 0.7 & 0.4 & 2.4 & 5.4 \\
\hline Dermaptera & Fam. Forficulidae & Predator & 0.0 & 0.0 & 0.0 & 0.0 \\
\hline Hemiptera & SubO. Heteroptera & Predator & 0.0 & 0.0 & 0.0 & 0.3 \\
\hline Neuroptera & Neuroptera larvae & Predator & 0.0 & 0.5 & 0.0 & 0.6 \\
\hline Pseudoscorpionida & O. Pseudoescorpionida & Predator & 0.0 & 3.2 & 4.4 & 3.5 \\
\hline Hemiptera & Fam. Reduviidae & Predator & 0.0 & 0.1 & 0.0 & 1.3 \\
\hline Dictioptera & SubO. Blattodea & Omnivour & 0.0 & 0.0 & 0.0 & 0.1 \\
\hline Diptera & SubO. Brachycera & Omnivour & 0.0 & 1.2 & 0.0 & 0.4 \\
\hline Hymenoptera & SuperFam. Chalcidoidea & Omnivour & 1.1 & 0.1 & 0.6 & 0.3 \\
\hline Hymenoptera & Fam. Formicidae & Omnivour & 0.6 & 0.2 & 0.5 & 0.2 \\
\hline Orthoptera & Fam. Gryllidae & Omnivour & 0.0 & 0.0 & 0.3 & 0.0 \\
\hline Hymenoptera & SuperFam. Ichneumonoidea & Omnivour & 1.3 & 1.7 & 3.2 & 7.9 \\
\hline Lepidoptera & O. Lepidoptera & Omnivour & 0.5 & 0.0 & 0.0 & 0.0 \\
\hline Diptera & SubO. Nematocera & Omnivour & 0.7 & 0.0 & 0.0 & 0.3 \\
\hline Psocoptera & O. Psocoptera & Omnivour & 0.0 & 0.0 & 0.0 & 0.1 \\
\hline SPECIES RICHNESS & & & 16 & 18 & 18 & 29 \\
\hline
\end{tabular}

